UDC 378.147:373

DOI https://doi.org/10.31470/2415-3729-2021-13-138-151

\title{
Formation of the English Language Competence of Future Pharmacists
}

\section{Olena Karasova}

Doctor of Philosophy in Pedagogy (Ph.D), Associate Professor, Associate Professor of Foreign Languages Department, National University of Pharmacy, $\triangle$ 53, Pushkinska Str., Kharkiv, Ukraine, 61022 E-mail: karasyovahelen@gmail.com ORCID: https://orcid.org/0000-0001-8922-9036

Date of receipt of the article: April 16, 2021 Article accepted for publication: June 02, 2021

\section{Формування фармацевтів \\ англомовної \\ компетентності \\ майбутніх}

\section{Олена Вячеславівна Карасьова}

кандидат педагогічних наук, доцент, доцент кафедри іноземних мов,

Національний фармацевтичний університет,

$\triangle$ вул. Пушкінська, 53, Харків, Україна

Дата надходження статті: 16 квітня 2021 р. Стаття прийнята до друку: 02 червня 2021 p.

\section{Absract}

The introduction to the article analyzes the current state of the future pharmacists' language competence, in particular English. The purpose of the study is to theoretically substantiate the essence of the concept of «English-language competence of future pharmacists» and highlight the features of its formation. Methods. In the process of fulfilling the goal a set of theoretical methods was used - analysis of scientific-methodical, psychological-pedagogical literature, study of normative-program documentation on the research topic. The results. Based on the analysis of the scientific literature, the essence of the concept of «professionoriented English-language competence» is clarified together with its links with professional competence, language and communication. The author specifies the meaning of «profession-oriented English-language 
competence» as a set of knowledge, practice-oriented skills, mastery of medical concepts, techniques of logical thinking aimed at solving profession-oriented situational problems, realization of discussions in the form of questions and answers on professional topics. Conclusions. The article identifies the peculiarities of forming the professionoriented English-language competence in teaching a foreign language to students of the pharmaceutical university: a foreign language in profession-oriented learning becomes not only the object of learning, but also a means of forming the students' profession-oriented Englishlanguage competence; mastering a foreign language is realized in practice-oriented language activities, the ability to participate in the communication of profession-oriented topics, and not in the knowledge of individual elements of a language; increasing the role of self-study work of students is caused by the constant development of modern technologies and innovations in pharmacy, increasing the amount of professional information and pharmaceutical terminology in English, which requires the future specialist skills and abilities to master information independently; the professional activity of pharmacists is connected with the formation and further development of their clinical thinking, professional and personal qualities (observation, flexibility, purposefulness, concentration, determination, communicative literacy).

Key words: students, pharmaceutical university, educational process, English-language competence, formation.

\section{References}

1. Bilianska, I. P. (2018). Formuvannia anhlomovnoi adytyvnoi kompetentnosti maibutnikh uchyteliv iz vykorystanniam audioknyh khudozhnikh tvoriv [Pre-service Teachers English Listening Competence Development Through Fiction Audiobooks]. Candidates thesis. Ternoril: Ternoril Volodymyr Hnatiuk National Redagogisal University [in Ukraine].

2. Biretska, L. S. (2015). Formuvannia anhlomovnoi leksychnoi kompetentnosti maibutnikh likariv $u$ profesiino oriientovanomu chytanni [Formation of English lexical competence of future doctors in profession-oriented reading]. Candidates thesis. Kyiv : Kyiv National Linguistic University [in Ukraine].

3. Horpinich, T. I. (2014). Metodyka formuvannia profesiinoi anhlomovnoi kompetentnosti u chytanni u maibutnikh farmatsevtiv 
z urakhuvanniam indyvidualno-kohnityvnykh styliv navchannia [Methodology of developing future pharmacists reading competency in professional English on the basis of individual cognitive styles of learning]. Candidates thesis. Ternoril: Ternoril Volodymyr Hnatiuk National Redagogisal University [in Ukraine].

4. Dolia, V. S. (2010). Mizhdystsyplinarna naukova leksyka farmakohnozii. [Interdisciplinary scientific vocabulary of pharmacognosy]. Teoretychni ta praktychni aspekty doslidzhennia likarskykh roslyn - Theoretical and practical aspects of research of medicinal plants. 12 (3), 145-148 [in Ukraine].

5. Krysak, L. V. (2016). Metodyka navchannia maibutnikh likariv zahalnoi praktyky anhlomovnoho profesiino oriientovanoho dialohichnoho movlennia [Methods of teaching future physicians of general practice of English profession-oriented dialogic speech]. Candidates thesis. Kyiv : Taras Shevchenko National University [in Ukraine].

6. Chorna, I. Yu. (2017). Formuvannia u maibutnikh marketolohiv anhlomovnoi leksychnoi kompetentnosti $\mathrm{v}$ pysmi zasobom keistekhnolohii [Formation of English Lexical Competence in Written Communication of Prospective Marketers by Means of Casetechnology]. Candidates thesis. Ternoril: Ternoril Volodymyr Hnatiuk National Redagogisal University [in Ukraine].

7. Ianenko, L. P. \& Yurchuk, L. V. (2014). Mozhlyvosti rozvyvaiuchoho navchannia dlia inshomovnoi kompetentsii studentiv [Opportunities for developmental learning for foreign language competence of students]. Mova i kultura-Language and culture, 17 (5), 88-92 [in Ukraine].

8. Laufer, B. (2003). Vocabulary Acquisition in a Second Language: do learners really acquire most vocabulary by reading? Some empirical evidence. Canadian Modern Language Review, 59 (4), 567-587.

9. Morska, L., Horpinich, T., Olendr, T. (2018). Teaching medical students professional English reading on the basis of individual cognitive learning styles. Science and Education, 2, 86-93.

10. Nation, P. (2005). Teaching Vocabulary. The Asian EFL Journal, 7 (3), 47-54.

11. Rusalkina, L. G. (2018). Integration of professional and linguistic disciplines of foreign-language orientation in the educational 
process of higher medical schools. European Journal of Humanities and Social Sciences, 6, 93-96.

\section{Ветуп}

Нині охорона здоров'я та суспільство відчувають дефіцит у фахівцях, які володіють іноземною мовою, здатні проводити професійно орієнтовану мовознавчу діяльність у професійному середовищі, освоювати нові досягнення зарубіжної фармації, брати участь у спільних наукових та практичних дослідженнях із зарубіжними партнерами. Л.Бірецька (2015) та Л.Крисак (2016) відзначають, що фармацевти, так i викладачі фармацевтичних університетів постають перед суттєвими труднощами при обробці професійної інформації з українських та іноземних джерел, спілкуванні з партнерами під час вирішення професійних проблем. Це зумовлює необхідність розробки нових технологій, методів та способів, спрямованих на професійно-орієнтоване навчання студентів у напрямі формування їхньої англомовної компетентності.

Аналіз результатів наукових досліджень надає підстави стверджувати, що створено теоретичні передумови на вирішення цієї проблеми.

Формуванню англомовної компетентності студентів під час навчання іноземної мови у немовних ЗВО присвячені дослідження багатьох авторів, до того ж вивчалися та були висвітлені такі питання, як: відбір та зміст навчального матеріалу під час навчання іноземної мови (Білянська, 2018; Чорна, 2017); психологопедагогічні умови засвоєння іноземної мови та розвитку мовної діяльності (Горпініч, 2014; Яненко, 2014); формування іншомовної професійної компетентності та розробка методичних підходів, технологій навчання іноземної мови (Доля, 2010; Laufer, 2003).

Однак, незважаючи на досить велику кількість досліджень, необхідно відзначити, що сучасне навчання іноземної мови у ЗВО, і зокрема у фармацевтичному університеті, потребує комплексного вдосконалення способів та засобів професійно орієнтованого навчання, спрямованого на організацію практико-орієнтованої навчальної діяльності з урахуванням постійно сучасних вимог суспільства, досягнень педагогічних та психологічних наук. 
Мета статті - теоретично обгрунтувати суть поняття «англомовна компетентність майбутніх фармацевтів» та висвітлити особливості іiі формування.

\section{Матеріал і методи дослідження}

Для досягнення поставленої мети дослідження було використано комплекс теоретичних методів - аналіз науково-методичної, психолого-педагогічної літератури, вивчення нормативнопрограмної документації за темою дослідження.

\section{Результати та їх обговорення}

Нині метою вивчення дисципліни «Іноземна мова» в фармацевтичному університеті $є$ професійно орієнтоване навчання іноземної мови майбутніх фармацевтів, формування основ іншомовної міжкультурної комунікації, оволодіння навичками спілкування іноземною мовою та застосування їх як засобу інформаційної діяльності та подальшої самоосвіти (Morska, 2018).

Л. Яценко (2014) вважає, що у сучасній ситуації підготовка фахівців вимагає докорінної зміни стратегії та тактики навчання, коли головною характеристикою випускника фармацевтичного університету є його компетентність.

Навчання іншомовному спілкуванню має бути орієнтоване на профіль спеціальності на підставі компетентнісного підходу, спрямованого на розвиток у студентів здатності самостійно вирішувати пізнавальні, комунікативні, організаційні, професійні завдання (Чорна, 2017).

Для уточнення змісту поняття «професійно орієнтована мовна компетентність» та встановлення iï зв'язків із професійною компетентністю, мовною та комунікативною компетентностями нами було проведено аналіз наукової літератури щодо цих питань.

За визначенням Т. Горпініч (2014), компетентність - це готовність людини до мобілізації знань, умінь та зовнішніх ресурсів для ефективної діяльності конкретної життєвої ситуації. Компетентність - це сукупність особистісних якостей здобувача освіти (ціннісних орієнтацій, знань, умінь, навичок, здібностей) здатність до діяльності у певній особистісно значущій галузі.

I. Білянська (2018) під компетентністю має на увазі характеристики фахівця, виражені через здатність діяти, що базується 
на єдності знань професійного досвіду та поведінки, відповідно до мети та ситуації.

Л. Бірецька (2018) зазначає, що компетентність можна визначити як комплекс (сукупність) знань, навичок та умінь, що формуються в процесі навчання що становить змістовний компонент навчання. Компетентність - це властивість особистості, іiі здатність до виконання будь-якої діяльності на основі сформованої компетентності.

В. Доля (2010) вважає, що компетентність - це володіння певними знаннями, вміннями та навичками, які можуть бути використані в діяльності, а компетентність - це ширше поняття і трактується автором як інтелектуальна, що грунтується на знаннях і особистісно зумовлена соціально-професійна діяльність людини.

Експерти країн Ради Європи, зокрема представники України, достатньо чітко визначають поняття компетенцій у документі Ради Європи «Загальноєвропейські компетенції володіння іноземною мовою: вивчення, викладання, оцінка» («Common European Framework of Reference: Learning, Teaching, Assessment»): компетенції представляють суму знань, умінь та особистісних якостей, які дозволяють людині виконувати різні дії.

Аналіз трактувань професійної компетентності, зроблений різними авторами, дозволив нам об'єднати та виділити основні характеристики, що розкривають це поняття: сукупність знань, умінь та володіння навичками професійної діяльності; здатність ефективно вирішувати професійні завдання та проблеми; здатність продуктивно працювати в професійному середовищі, володіти необхідним набором компетенцій для здійснення професійної діяльності; бути конкурентоспроможним.

У навчанні іноземних мов компетентність може трактуватись вузько - як сукупність знань, навичок, умінь, що формуються в процесі навчання, та ширше - як практико-орієнтоване володіння мовними знаннями, навичками та мовними вміннями (Горпініч, 2014).

У багатьох роботах дослідників йдеться про нову компетентну модель освітнього процесу, яка передбачає створення умов для формування ключових лінгвістичних компетенцій, «відрефлексованих учнями знань та досвіду комунікації іноземною мовою, які слу- 
жать формуванню професійної мовної особистості» (Nation, 2005; Rusalkina, 2018).

Проблемою англомовної компетентності займалася ціла низка вчених. Так, L. Morska, T. Horpinich, T. Olendr (2018) розуміє англомовну компетентність як знання фонетичних, лексичних та граматичних моделей мовної системи, а також уміння оперувати ними у своєму висловленні. На думку вчених, англомовна компетентність - це здатність вирішувати загальнокультурні (спілкуватися, працювати з інформацією, писати ділові листи, резюме) та професійні завдання (відбір та презентація спеціальних матеріалів, анотування, переклад, участь у проєкті).

P. Nation (2005) дає визначення мовної компетентності як якості особистості, характеризується комплексом знань, умінь та навичок, що забезпечують індивіду можливість сприймати, розуміти та породжувати повідомлення (тексти), що містять інформацію, виражену засобами природної мови, зберігати таку інформацію в пам'яті та обробляти їі в ході розумових процесів.

Незважаючи на деякі відмінності в інтерпретації поняття «англомовна компетентність» різними авторами, нами виділено загальні ii характеристики достатній рівень лінгвістичних знань одиниць мови та їх функцій; володіння правилами функціонування мови; володіння англомовними засобами, необхідні мовних контактів у мовному співтоваристві; володіння навичками адекватного сприйняття та породження іншомовного тексту; готовність та здатність до комунікації в іншомовному середовищі.

I. Чорна (2017) зазначає, що однією 3 цілей навчання іноземними мовами є формування комунікативної компетентності, яка розглядається як єдність, що складається 3 кількох складових - лінгвістичної (мовної), соціолінгвістичної, соціокультурної, стратегічної, дискурсивної, соціальної компетентностей.

Вчені також вказують на те, що мовна та комунікативна компетентності тісно взаємопов'язані, вони формуються та розвиваються в процесі іншомовної підготовки студента, є важливим аспектом професійної підготовки.

3 вивчення наукової літератури встановлено, що це компетентності - професійна, мовна, комунікативна тісно взаємопов'язані, доповнюють одна одну та їх загальний вплив 
дозволяє значно підвищити рівень та якість підготовки майбутніх фармацевтів.

Останнім часом проводяться дослідження, які стосувалися підвищення якості викладання іноземної мови та формування іншомовної, мовної компетентностей в немовних ЗВО. Ці роботи велися практично в одному напрямі раціоналізації та оптимізації методики навчання іноземної мови, зокрема англійської, - і стосувалися вдосконалення технологій, методів комунікативної діяльності.

Все вищевикладене підтверджує те положення, що однією 3 основних цілей вищого професійного навчання майбутнього фармацевта $\epsilon$ формування його професійно-орієнтованої англомовної компетентності.

Однак, незважаючи на досить велику кількість досліджень у вітчизняної та зарубіжної літератури, необхідно зазначити, що сучасне навчання іноземної мови у фармацевтичному університеті потребує комплексного вдосконалення способів, засобів, організації практико-орієнтованого навчання, спрямованого на формування професійно орієнтованої англомовної компетентності, з урахуванням постійно оновлюваних вимог суспільства, досягнень педагогічних та психологічних наук та їі ролі як інструменту формування професійної компетентності та підвищення якості професійної підготовки, тобто проблема формування професійно орієнтованої англомовної компетентності потребує додаткового вивчення.

Недостатньо розглянуто питання розвитку мовної діяльності, способи, умови та засоби навчання іноземної мови з метою формування професійно орієнтованої англомовної компетентності студентів фармацевтичного університету.

Неповністю розкрито роль та можливість англомовної підготовки у формуванні професійних якостей майбутнього фармацевта в контексті його специфіки професійної діяльності Розглядаючи зміст поняття «професійно орієнтована англомовна компетентність», слід зазначити, що особливість формування англомовної компетентності обумовлена іiі професійною орієнтацією.

На наш погляд, поняття «професійна орієнтація» необхідно запровадити у зв'язку з тим, що у фармацевтичному університеті основною метою є не вивчення іноземної мови, а підготовка майбутньо- 
го фахівця до здійснення своєї діяльності з профілю ЗВО, у нашому випадку це підготовка фармацевта.

У цьому контексті поняття «професійна орієнтація навчання іноземної мови сприймається як процес навчання, у якому освітне середовище, способи навчання іноземної мови роблять цей процес інструментом підвищення якості професійної підготовки та формування професійної компетентності, у зв'язку з чим вектор навчання англійської мови у фармацевтичному університеті, його цілі, завдання, застосовувані способи навчання спрямовані та орієнтовані на майбутнього фахівця та його професію. Слід зазначити, що ми стверджуємо не «професійна англомовна компетентність», а додаємо до цього поняття слово «орієнтована», тобто, «професійно орієнтована англомовна компетентність», тим самим наголошуємо, що процес навчання англійської мови у фармацевтичному ЗВО - це як його професійна спрямованість, а й його загальнокультурна роль.

Професійно-орієнтована англомовна компетентність $є$ сукупність знань, практико-орієнтованих умінь, володіння фармацевтичними поняттями, прийомами логічного мислення, спрямованими на вирішення професійно орієнтованих ситуаційних завдань, обговорення в питання безперекладної форми у відповідь на професійні теми.

Розглядаючи діалектичний взаємозв'язок проаналізованих понять (професійна компетентність, англомовна компетентність, комунікативна компетентність, професійно орієнтована англомовна компетентність), ми встановили, що сполучною ланкою цих понять $є$ те, що їх вектор напряму орієнтований на підвищення якості та оптимізацію професійної підготовки випускника фармацевтичного університету, підвищення рівня формування компетентностей, що належать до взаємодії у соціальній сфері; компетентностей, що відносяться до діяльності людини.

Враховуючи це, ми провели аналіз психолого-педагогічної літератури та наукових досліджень, що розкривають особливості, які можуть впливати на формування професійно орієнтованої англомовної компетентності майбутніх фармацевтів у процесі професійно орієнтованого навчання іноземної мови. 
I. Чорна (2017) однією з особливостей навчання іноземної вважає те, що засвоєння іiі йде шляхом, протилежним тому, яким іде розвиток рідної мови. Здобувач освіти засвоює рідну мову неусвідомлено і ненавмисно, а іноземну, зокрема англійську, - починаючи з усвідомлення та навмисності. Це підтверджує принцип свідомості під час навчання іноземної мови.

Вивчення іноземної мови у фармацевтичному університеті може впливати на формування комунікативної культури майбутнього фармацевта при розвитку його індивідуально-особистісної орієнтації, диференціації та гуманізації взаємовідносин у процесі всіх його учасників; неперервності та спадкоємності комунікативної підготовки.

Отже, проведений аналіз наукової літератури надає підстави стверджувати, що особливостями діяльності фармацевта в системі «людина - людина» $є$ не тільки його знання та вміння, особливості професійного мислення, а й особисті якості та вміння. Тому професійна компетентність фармацевта включає не лише високий рівень спеціальної фармацевтичної підготовки, загальнолюдської культури, а також соціально-психологічні аспекти його особистості, його ціннісні орієнтації, комунікативну грамотність.

\section{Висновки}

Конкретизовано зміст поняття «професійно орієнтована англомовна компетентність», яка $є$ сукупністю знань, практико орієнтованих умінь, володіння фармацевтичними поняттями, прийомами логічного мислення, спрямованими на рішення професійно орієнтованих ситуаційних завдань, проведення дискусії у формі запитань-відповідей на професійні теми.

Особливостями формування професійно орієнтованої англомовної компетентності під час навчання іноземної мови студентів фармацевтичного університету є: іноземна мова при професійно орієнтованому навчанні стає не лише об'єктом засвоєння, а й засобом формування професійно орієнтованої англомовної компетентності студентів; оволодіння іноземною мовою реалізується у практико-орієнтованій мовній діяльності, здатності брати участь у спілкуванні професійно орієнтовані теми, а чи не у знанні окремих елементів мови; підвищення 
ролі самостійної роботи студентів викликано постійним розвитком сучасних технологій та інновацій у фармації, збільшенням обсягу професійної інформації та фармацевтичної термінології англійською мовою, що вимагає від майбутнього фахівця умінь та навичок самостійного оволодіння інформацією; професійна діяльність фармацевта пов'язана 3 формуванням та подальшим розвитком його клінічного мислення, професійно-особистісних якостей: спостережливість, гнучкість, цілеспрямованість, концентрованість, рішучість, комунікативна грамотність.

Перспективи подальших розвідок вбачаємо у теоретичному обгрунтуванні технології формування англомовної компетентності студентів фармацевтичних університетів.

\section{Література}

1. Білянська I. П. Формування англомовної адитивної компетентності майбутніх учителів із використанням аудіокниг художніх творів: дис. ... канд. пед. наук: 13.00.02 / Терноп. нац. пед. ун-т імені Володимира Гнатюка. Тернопіль, 2018. 316 с

2. Бірецька Л. С. Формування англомовної лексичної компетентності майбутніх лікарів у професійно орієнтованому читанні: автореф. дис. ... канд. пед. наук: 13.00.02 / Київ. нац. лінгв. ун-т. Київ, 2015. 22 с.

3. Горпініч T. I. Методика формування професійної англомовної компетентності у читанні у майбутніх фармацевтів 3 урахуванням індивідуально-когнітивних стилів навчання: дис. ... канд. пед. наук: 13.00.02 / Терноп. нац ун-т імені Володимира Гнатюка. Тернопіль, 2014. 300 с.

4. Доля В. С. Міждисциплінарна наукова лексика фармакогнозії. Теоретичні та практичні аспекти дослідження лікарських рослин. 2010. № 12, Т. 3. С. 145-148.

5. Крисак Л. В. Методика навчання майбутніх лікарів загальної практики англомовного професійно орієнтованого діалогічного мовлення: дис. ... канд. пед. наук: 13.00.02 / Київ. нац ун-т імені Тараса Шевченка. Київ, 2016. 285 с.

6. Чорна I. Ю. Формування у майбутніх маркетологів англомовної лексичної компетентності в письмі засобом кейстехнології: дис. ... канд. пед. наук: 13.00.02 / Терноп. нац. пед ун-т ім. Володимира Гнатюка, Тернопіль, 2017. 268 с. 
7. Яненко Л. П., Юрчук Л. В. Можливості розвиваючого навчання для іншомовної компетенції студентів. Мова і культура. 2014. Вип. 17, Т. 5. С. 88-92.

8. Laufer B. Vocabulary Acquisition in a Second Language: do learners really acquire most vocabulary by reading? Some empirical evidence. Canadian Modern Language Review. 2003. № 59 (4). P. $567-587$.

9. Morska L., Horpinich T., Olendr T. Teaching medical students professional English reading on the basis of individual cognitive learning styles. Science and Education. 2018. № 2. P. 86-93.

10. Nation P. Teaching Vocabulary. The Asian EFL Journal. 2005. Vol. 7. Issue 3. P. 47-54.

11. Rusalkina L. G. Integration of professional and linguistic disciplines of foreign-language orientation in the educational process of higher medical schools. European Journal of Humanities and Social Sciences. 2018. № 6. P. 93-96.

\section{Карасьова О.В.}

\section{Формування \\ англомовної \\ компетентності \\ майбутніх фармацевтів}

\section{Анотація}

У вступі статті проаналізовано сучасний стан мовної компетентності майбутніх фармацевтів, зокрема англомовної. Метою дослідження $є$ теоретичне обгрунтування суті поняття «англомовна компетентність майбутніх фармацевтів» та висвітлення особливостей ii формування. У процесі виконання мети було використано комплекс теоретичних методів - аналіз науково-методичної, психолого-педагогічної літератури, вивчення нормативно-програмної документації за темою дослідження. На основі проведеного аналізу наукової літератури уточнено зміст поняття «професійно орієнтована англомовна компетентність» та встановлено іiі зв'язки із професійною компетентністю, мовною та комунікативною. Автором конкретизовано зміст поняття «професійно орієнтована англомовна компетентність», яка $є$ сукупністю знань, практико орієнтованих умінь, володіння фар- 
мацевтичними поняттями, прийомами логічного мислення, спрямованими на рішення професійно орієнтованих ситуаційних завдань, проведення дискусії у формі запитань-відповідей на професійні теми. У статті визначено особливостями формування професійно орієнтованої англомовної компетентності під час навчання іноземної мови студентів фармацевтичного університету: іноземна мова при професійно орієнтованому навчанні стає не лише об'єктом засвоєння, а й засобом формування професійно орієнтованої англомовної компетентності студентів; оволодіння іноземною мовою реалізується у практико-орієнтованій мовній діяльності, здатності брати участь у спілкуванні професійно орієнтовані теми, у знанні окремих елементів мови; підвищення ролі самостійної роботи студентів викликано постійним розвитком сучасних технологій та інновацій у фармації, збільшенням обсягу професійної інформації та фармацевтичної термінології англійською мовою, що вимагає від майбутнього фахівця умінь та навичок самостійного оволодіння інформацією; професійна діяльність фармацевта пов'язана 3 формуванням та подальшим розвитком його клінічного мислення, професійно-особистісних якостей: спостережливість, гнучкість, цілеспрямованість, концентрованість, рішучість, комунікативна грамотність.

Ключові слова: студенти, фармацевтичний університет, освітній процес, англомовна компетентність, формування.

Карасева Е. В.

\section{Формирование англоязычной компетентности будущих фар- мацевтов}

\section{Аннотация}

Во введении статьи проанализировано современное состояние языковой компетентности будущих фармацевтов, в том числе англоязычной. Целью исследования является теоретическое обоснование понятия «англоязычная компетентность будущих фармацевтов» и освещение особенностей ее формирования. В процессе выполнения цели был использован комплекс теоретических методов - анализ научно-методической, психолого-педагогической 
литературы, изучение нормативно программной документации по теме исследования. На основе проведенного анализа научной литературы уточнено содержание понятия «профессионально ориентированная англоязычная компетентность» и установлено ее связи с профессиональной компетентностью, языковой и коммуникативной. Автором конкретизировано содержание понятия «профессионально ориентированная англоязычная компетентность», являющаяся совокупностью знаний, практико ориентированных умений, владения медицинскими понятиями, приемами логического мышления, направленными на решение профессионально ориентированных ситуационных задач, проведение дискуссии в форме вопросов-ответов. В статье определено особенности формирования профессионально ориентированной англоязычной компетентности во время обучения иностранному языку студентов фармацевтического университета. Профессиональная деятельность фармацевта связана с формированием и дальнейшим развитием его клинического мышления, профессионально личностных качеств: наблюдательность, гибкость, целеустремленность, концентрированность, решительность, коммуникативная грамотность.

Ключевые слова: студенты, фармацевтический университет, образовательный процесс, англоязычная компетентность, формирование. 